\title{
A STUDY OF \\ NESTING CANADA GEESE \\ AT CONDIE NATURE REFUGE, SASKATCHEWAN
}

ANN MARSHALL, Saskatchewan Museum of Natural History, Regina, Saskatchewan, S4P $3 V 7$.

The Condie Nature Refuge (Map 1) is located approximately $16 \mathrm{~km}$ northwest of Regina on No. 11 highway. The reservoir was created in 1924 by the C.N.R. to provide water for their locomotives, and in 1961 was acquired by Saskatchewan Tourism and Renewable Resources (then Dept. of Natural Resources) for preservation of the marsh and grassland as a nature refuge and recreation site. The 273.2-ha area is now intensively used for outdoor recreation by Regina schools. The reservoir and marsh provide a nesting and staging area for Canada Geese and some species of ducks.

The geese at Condie are mostly descendants from the Wascana Centre flock in Regina. Most of these geese are now crosses of Branta canadensis maxima and B. C. moffiti which are slightly smaller than $B$. $C$. maxima (Scott, personal com. munication).

From 11 May to 12 June, 1978 a nesting survey of Canada geese was conducted to determine nest numbers and locations, hatching success and gosling survival. A canoe was used to gain access to the islands and marshy areas. The author was aided by Rhonda Phillips and Larry Bogdan.

In addition to an academic interest in the numbers and success of nesting geese, the purpose of the study was to determine which areas of the refuge are most used by nesting and brood-rearing birds. The information gained may be used in planning of future interpretive developments, such as observation blinds or walking trails, so that disturbance of the geese may be minimized by people using the area.

\section{Nests}

Table 1 is a summary of the results of the nest survey.

A small island (A), in map 1 , in the waterfowl sanctuary contained eight nests (37 eggs). The vegetation consisted of many willow bushes with sparse ground cover at the beginning of the survey. By the end of the survey the nests were well concealed by increased vegetation. The substrate was dry. Six nests containing 24 eggs were abandoned. The other two nests hatched ten eggs.

Roosting Island (B) is small, has banked edges and little vegetative cover. This island was not checked until mid-way through the survey so the total number of eggs laid cannot be determined. There were two nests. One appeared to have already hatched and there was one egg beside the nest. The other nest hatched two eggs. Four eggs with holes in their sides, scattered near this nest, indicated predation. No definite conclusions can be made about success of eggs on this island, 
TABLE 1. Summary of Canada goose nest locations, egg production, clutch sizes, nesting success and hatching success at Cor đie Nature Refuge, Summer, 1978.

\begin{tabular}{|c|c|c|c|c|c|c|}
\hline Location & $\begin{array}{l}\text { Number } \\
\text { of nests }\end{array}$ & $\begin{array}{l}\text { Number } \\
\text { of eggs }\end{array}$ & $\begin{array}{l}\text { Average } \\
\text { number } \\
\text { of eggs } \\
\text { per } \\
\text { clutch }\end{array}$ & $\begin{array}{l}\text { Number } \\
\text { of eggs } \\
\text { hatched }\end{array}$ & $\begin{array}{l}\text { \% nests } \\
\text { successful } \\
\text { (hatched at } \\
\text { least } 1 \\
\text { egg) }\end{array}$ & $\begin{array}{l}\% \text { egg } \\
\text { hatche }\end{array}$ \\
\hline Island A & 8 & 37 & 4.6 & 10 & 25 & 27 \\
\hline Island $B^{* *}$ & 2 & $7\left(\mathrm{Min}^{*}\right)$ & 3.5(Min) & 2 (Min) & 50(Min) & 28.51 \\
\hline Peninsula C & 4 & 21 & 5.25 & 13 & 50 & 61.9 \\
\hline Peninsula D & 2 & 10 & 5.0 & 10 & 100 & 100 \\
\hline Picnic Area & 2 & 8 & 4.0 & 7 & 100 & 87.5 \\
\hline Creek $^{\star \star \star}$ & 2 & 9 & 4.5 & 5(Min) & 50(Min) & 55.51 \\
\hline Other & 5 & 34 & 6.8 & 32 & 100 & 94.1 \\
\hline TOTALS & 25 & 126(Min) & $5.04(\mathrm{Min})$ & 79 (Min) & 76(Min) & 62.6 \\
\hline \multirow[t]{2}{*}{ **|sland B } & 1 & 1 (Min) & 1 (Min) & $?$ & $?$ & $?$ \\
\hline & 1 & 6(Min) & 6(Min) & 2 & 100 & 33 \\
\hline \multirow[t]{2}{*}{${ }^{\star *}$ Creek } & 1 & 5 & 5.0 & 5 & 100 & 100 \\
\hline & 1 & 4 & 4.0 & $?$ & $?$ & $?$ \\
\hline
\end{tabular}

In the morning, the popular areas for the geese and goslings to feed were on the grass by the picnic shelter and in the lure crop field. A few families were observed on the grassy southwest shore and by the pond on the northeast side of the highway.

\section{Discussion}

When selecting nest sites Canada geese consider the following: 1) abundance of nesting material, 2) island nest sites, 3) closeness to water, 4) firmness of nesting substrate, 5) closeness of grazing area, 6) presence of loafing sites, 7) absence of other nests, 8) good visibility from nest sites and, 9) a closeness of brood rearing area. 1

At Condie Nature Refuge all nests were close to water and had good visibility, at least at the beginning of the nesting season. The lure crop field and lawns provide grazing areas and goslings can be hidden in the long grass and reeds. The island nest sites were the least successful, probably because of crowding and interactions between pairs. The most successful nests were along the shore and on the dry section of a marshy peninsula. The other three islands (Map 1) are only reed beds; there is no firm substrate.

At Condie, the average clutch size was 5.0, the nesting success was $76 \%$ and the hatching success was $62.6 \%$. These results are comparable to other studies. At Waterhen Marsh, Saskatchewan, the average clutch size was 5.6, average nesting success was $82.7 \%$ and hatching success was $77.4 \% .1$ Clutch sizes at Marshy Point, Manitoba, averaged 5.7 in 1969 and 5.6 in 1970 and 1971.2 Nest success ranged from a low of $65 \%$ in 1970 to $82 \%$ in 1971 and egg success averaged $67 \%$.2 

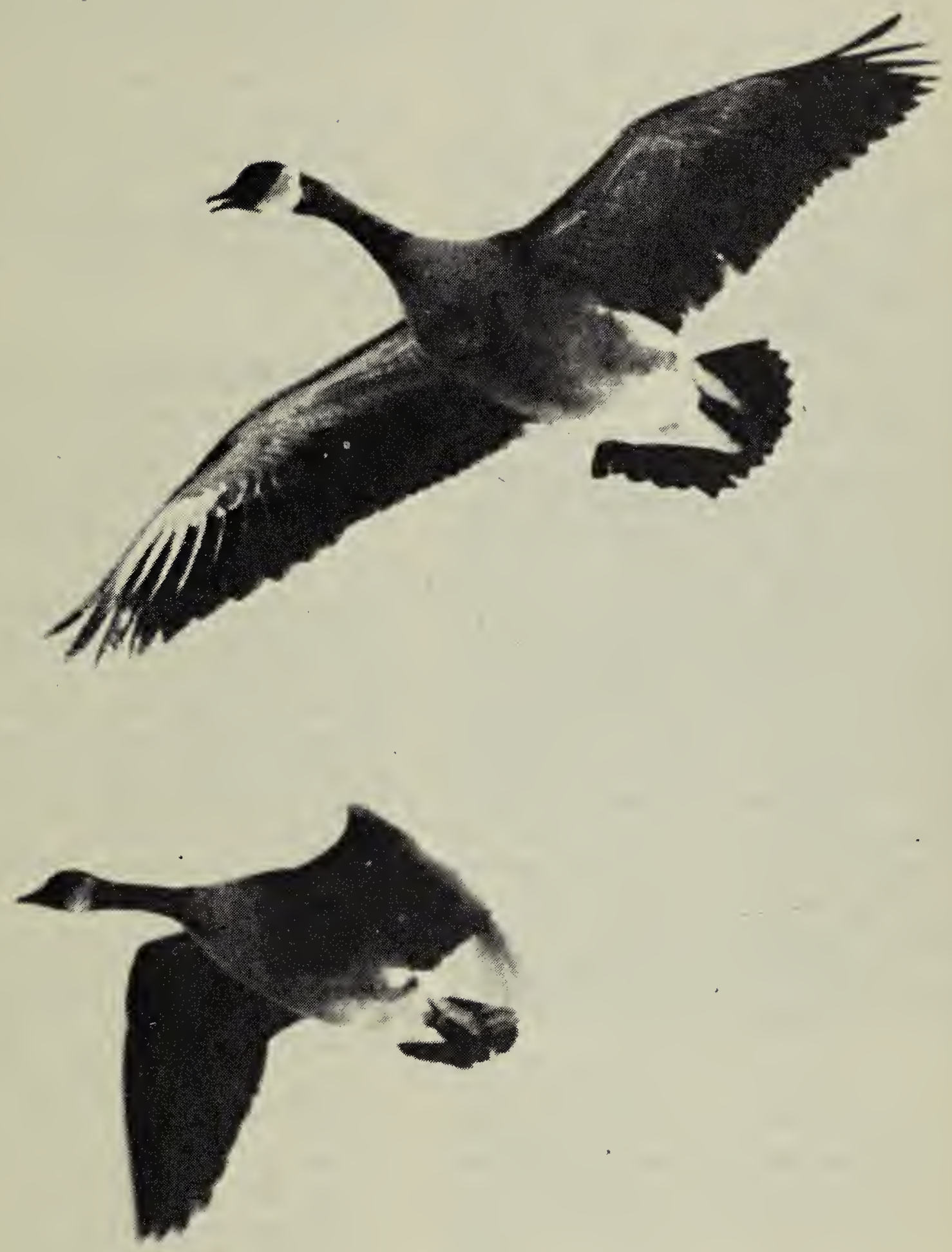

The following information is from Wascana Centre (L. Scott, personal communication). In 1978 there were 250 nests $(1,400$ eggs) on Wascana Lake with an average clutch size of September, 1979. 37(3)
5.6 eggs. In 1977 average clutch size was 4.5 and in 1976 was 6.0. Only 700 goslings were raised in 1978 for a success rate of $50 \%$. All the nests at Wascana were on islands or in 
fenced areas so there was little harassment by dogs or humans. There are a few mink but their effect on nests is not known. Territorial combats between geese resulted in a high number of abandoned nests.

At Condie there appeared to be a $43 \%$ loss of goslings from the 79 eggs hatched, to make a total success rate of only $36 \%$. This apparent loss is inexplicable. Only one dead gosling was found. Possibly the goslings were taken into other brood-rearing areas. At Waterhen Marsh, observed mortality prior to brood mixing and for coloured broods less than 2 weeks old was about $7 \% .1$ However, at the end of the flightless period there appeared to be a reduction of $65 \%$. It was assumed that there were unknown brood-rearing areas. 1 In Utah average mortality during brood rearing was only $7 \%$ for 3 years combined; most mortality probably occurred in the week following hatching. ${ }^{3}$ At Seney National Wildlife Refuge, Michigan, gosling survival rates were $16 \%$ in $1964,78 \%$ in 1963 and $72 \%$ in 1965 with most mortality probably in the first 3 to 4 weeks. ${ }^{4}$ Predation appeared to be the main limiting factor on goose production although disease was also important. 4

Very few of the geese were protective of their nests or goslings against human interference. In Michigan, it was also found that goose pairs would usually depart rather than defend. 4

Six nests or $24 \%$ of the nests at Condie Nature Refuge were deserted for reasons unknown. Flooding appeared to be the reason in two of the nests and predation in at least two. Other causes for nest loss are destruction, infertile eggs and embryo death.

\section{Conclusions}

The productivity of geese at Condie Nature Refuge was a little lower than in other studies. Perhaps the area could be improved by providing other nesting sites. At Marshy Point, Manitoba, nest success was highest (77\%) among nests in nest boxes and on muskrat houses and lowest (69\%) for ground nests. ${ }^{2}$ Nest success on islands at Condie was very low likely due to overcrowding. A few artificial nesting structures could be installed to determine if geese would use them.

\section{Acknowledgements}

The author wishes to acknowledge Rhonda Phillips and Larry Bogdan who assisted with the field study and Dr. Alex Dzubin, Canadian Wildlife Service and Ron Boychuk, Ducks Unlimited, who provided reference material for the report. Also thanks to staff members of Fisheries and Wildlife Branch, Saskatchewan Tourism and Renewable Resources, and to Dave Baron for critical reading of the manuscript.

1BRACE, R. K. 1972. A study of the nesting ecology, productivity, and mortality of Canada geese at Waterhen Marsh, Saskatchewan. M.Sc. Thesis, University of Saskatchewan, Regina Campus, Regina, Saskatchewan. 162 pp.

2 COOPER, J. A. 1978. The history and breeding biology of the Canada goose of Marshy Point, Manitoba. Wildlife Monogr. No. 61. 87 pp.

3MARTIN, F. W. 1964. Behaviour and survival of Canada geese in Utah. Utah Dept. Fish Game Bull. No. 64(7): 89 pp.

${ }^{4}$ SHERWOOD, G. A. 1965. Canada geese of the Seney National Wildlife Refuge. Completion Rept. for Wildlife Management Studies No. 1 and No. 2, Seney National Wildlife Refuge, Seney, Michigan. 177 pp. 